\title{
Influence of Pool Detergents on Formation of Chloramines in Swimming Pool Water ${ }^{4}$
}

\begin{abstract}
Cleaning agents used in swimming pools are essential elements in maintaining the proper hygiene of a swimming pool facility. They can also pollute water and cause a potential health hazard for swimming pool users. Studies show that the combination of substances used for disinfection with some contaminations presented in pool water can cause the formation of many dangerous by-products. One of these is chloramines, which have carcinogenic and mutagenic properties; this is why an analysis of the factors that influence their formation is very important. The purpose of this article is to determine the effect of pool detergents used on swimming pools on the formation of chloramines in pool water. Samples of swimming pool water were treated with selected detergents (Benamin AKR, Benamin SND, Randklar A, and Randklar S) used in one of Krakow's public swimming pools and then tested for monochloramine, dichloramine, and trichloride. The results may be helpful in taking the steps to mitigate the negative effects of using cleaning agents.
\end{abstract}

Keywords: disinfection by-products, chloramines, cleaning detergents, pool chemistry, swimming pool water

Received: 10 January 2019; accepted: 12 June 2019

1 AGH University of Science and Technology, Faculty of Mining Surveying and Environmental Engineering, Department of Environmental Management and Protection, Krakow, Poland, email: stankowska@agh.edu.pl

2 AGH University of Science and Technology, Faculty of Mining Surveying and Environmental Engineering, Department of Environmental Management and Protection, Krakow, Poland, email: wlodyka@agh.edu.pl ORCID ID: https://orcid.org/0000-0001-5045-7314

3 AGH University of Science and Technology, Faculty of Mining Surveying and Environmental Engineering, Department of Environmental Management and Protection, Krakow, Poland, email: tbergier@agh.edu.pl

ORCID ID: https://orcid.org/0000-0002-6780-077X

4 The paper has been prepared within the scope of the AGH UST statutory research No. 15.11.150.467 


\section{Introduction}

Cleaning agents used in swimming pools are essential elements for maintaining the proper hygiene of a swimming pool facility. They facilitate the removal of various types of pollutants that are introduced by people using swimming pools, settling on the walls as well as the bottom of the water pools. The composition of the pool chemistry is varied. These preparations are composed of alcohols, tensides (surfactants), acids (acetic, phosphoric, saline), alkalis (potassium, sodium), fragrances (used for neutralizing the odors of acids and tensides), preservatives, inhibitors (they bind oxygen that escapes into the air in the package when the detergent portion is consumed), and others [1]. These substances are effective in removing dirt but can be harmful to human health when their concentrations are too high. Therefore, the pool chemistry should be appropriately chosen so that it performs its task at the lowest possible concentrations. It should not be an additional source of pool water pollution. Despite the important role they play, there is currently no research on the impact of cleaning agents on pool water quality. In Poland, the quality of swimming pool water is regulated by the Regulation of the Minister of Health of November 9, 2015, on the requirements for water in swimming pools. One of the parameters that requires control is the disinfection by-products (DBPs). They constitute an undesirable group of substances arising from the reaction of disinfectants with impurities [2]. Their presence was first discovered in 1970 [3] and is a problem that is widely described in the literature [4-6]. DBP precursors can include secretions from the human body, chemicals used in cosmetics, and natural organic matter, among others [7]. Depending on the disinfectant used, DBPs can be divided into organic and inorganic compounds. Although they exist in grams per liter of water, they are classified as genotoxic, mutagenic, or carcinogenic $[4,8]$. Studies show that the by-products of pool water disinfection can increase the risk of bladder cancer [9], liver cancer [10], and respiratory tract infections [7].

Chloramines are one of the DBPs; these are inorganic compounds that have one or more chlorine atoms attached to the nitrogen atom [11]. Among them, we can distinguish monochloramine $\left(\mathrm{NH}_{2} \mathrm{Cl}\right)$, dichloramine $\left(\mathrm{NHCl}_{2}\right)$, and trichloramine $\left(\mathrm{NCl}_{3}\right)$. Chloramines are particularly onerous for bathers because of their irritating properties. These compounds (especially trichloramine) are volatile and can irritate the mucous membranes of the eyes, skin, and respiratory tract [12]. This problem is particularly felt by professional swimmers and swimming pool staff $[10,13]$. The increased risk of asthma as an occupational disease caused by the inhalation of trichloramine in the air was reported by Thickett in his work. He showed that trichloramine levels between 100 and $570 \mu \mathrm{g} / \mathrm{m}^{3}$ increase the incidence of asthma in swimming pool staff [14], while a Swiss study showed irritant effects among pool workers at levels as low as $200-300 \mu \mathrm{g} / \mathrm{m}^{3}$ [13]. In addition, nitrogen trichloride $\left(\mathrm{NCl}_{3}\right)$ has a strong and unpleasant odor, with irri- 
tating effects in concentrations of $0.02 \mathrm{mg} / \mathrm{dm}^{3}$ in the water [15] and $0.5 \mathrm{mg} / \mathrm{m}^{3}$ in the air [11].

The purpose of the article was to determine the effect of using chlorine-based cleaning agents on chloramine creation in swimming pools. This issue is especially important due to the lack of research in this area and the limited regulations concerning the use of pool chemistry. Analysis of the factors that can potentially influence the formation of DBPs will allow us to better deal with their undesirable effects and protect human health. The obtained results may be helpful in taking action to mitigate the negative effects of using pool cleaners.

\section{Materials and Methods}

Water was taken for analysis from the basin of the training pool at AGH University in Krakow. The experiment was carried out under laboratory conditions, where the selected detergents were diluted with pool water to form $0.01 \%$ solutions. The characteristics of the used agents are shown in Table 1. The water samples were tested for chloramine-formation potential. A modified test developed by Cimetiere and de Laat [16] was used for checking the ability of by-product production in pool water. The samples of water were chlorinated with sodium hypochlorite (concentration $-3 \mathrm{mg} / \mathrm{dm}^{3}$ ) and incubated at $25^{\circ} \mathrm{C}$ for $24 \mathrm{~h}$. Since the effects of cleansing agents are often based on surface treatment of not only the ingredients of these agents but also their extreme $\mathrm{pH}$ levels, the $\mathrm{pH}$ was not set in the potential test. In addition, the water's content of phosphorus, total nitrogen, chemical oxygen demand (COD), $\mathrm{pH}$, and conductivity was determined. Nitrogen and phosphorus were photometrically measured using Nanocolor tests on an Aurius 2021 UV VIS Spectrophotometer (Cecil Instruments). The reaction and electrical conductivity were determined by electrometric methods in accordance with PN-EN ISO 10523: 2012 and PN-EN 27888: 1999.

Table 1. Characteristic of tested detergents

\begin{tabular}{|c|c|c|c|}
\hline Name & Composition & Designation & Reaction \\
\hline Benamin AKR & $\begin{array}{l}\text { sodium hydroxide, active ingre- } \\
\text { dients, auxiliaries, fragrances, and } \\
\text { nonionic surfactants }\end{array}$ & \multirow{2}{*}{$\begin{array}{l}\text { designed to } \\
\text { remove organic } \\
\text { deposits, fats, oils, } \\
\text { cosmetic residue }\end{array}$} & \multirow[t]{2}{*}{ base } \\
\hline Randklar A & $\begin{array}{l}<25 \% \text { potassium hydroxide, biode- } \\
\text { gradable surfactant }\end{array}$ & & \\
\hline Benamin SND & $\begin{array}{l}\text { Phosphoric acid }<25 \% \text { nonionic and } \\
\text { cationic surfactants }\end{array}$ & \multirow{2}{*}{$\begin{array}{l}\text { designed for } \\
\text { removing } \\
\text { inorganic and } \\
\text { limestone deposits }\end{array}$} & \multirow[b]{2}{*}{ acid } \\
\hline Randklar S & $\begin{array}{l}<25 \% \text { hydrochloric acid }<10 \% \text { ortho- } \\
\text { phosphoric acid, corrosion inhibi- } \\
\text { tors, biodegradable surfactants }\end{array}$ & & \\
\hline
\end{tabular}




\section{Results and Discussion}

Results of the physico-chemical analyses of the examined water samples are presented in Table 2 .

Table 2. Psysico-chemical parameters of swimming pool water

\begin{tabular}{||l|c|c|c|c|c||}
\hline \hline \multicolumn{1}{|c|}{ Water sample } & $\begin{array}{c}\mathrm{pH} \\
{[-]}\end{array}$ & $\begin{array}{c}\text { Conductivity } \\
{[\mathrm{mS} / \mathrm{cm}]}\end{array}$ & $\begin{array}{c}\mathrm{COD} \\
{\left[\mathrm{mg} \mathrm{O}_{2} / \mathrm{dm}^{3}\right]}\end{array}$ & $\begin{array}{c}\mathrm{N}_{\text {og }} \\
{\left[\mathrm{mg} / \mathrm{dm}^{3}\right]}\end{array}$ & $\begin{array}{c}\mathrm{P}_{\text {og }} \\
{\left[\mathrm{mg} / \mathrm{dm}^{3}\right]}\end{array}$ \\
\hline \hline Pool water (B0) & 6.80 & 1.28 & 3.08 & 6.1 & $<\mathrm{DL}^{*}$ \\
\hline B0+Benamin SND & 4.10 & 1.37 & 3.08 & 5.4 & 8.80 \\
\hline B0+Benamin AKR & 8.76 & 1.35 & 3.08 & 5.7 & 0.81 \\
\hline B0+Ranklar S & 3.30 & 1.28 & 4.62 & 5.5 & 3.10 \\
\hline B0+Ranklar A & 7.60 & 1.35 & 3.08 & 5.3 & 0.47 \\
\hline
\end{tabular}

* limit of analytical determination, DL (detection limit).

Based on the results, it was found that the $\mathrm{pH}$ value of the pool water did not exceed permissible standards (6.5-7.6) specified in the Regulation of the Minister of Health of November 9, 2015, on the requirements for swimming pool water [17]. The addition of cleaning agents changed the $\mathrm{pH}$ of the pool water each time. Although the concentration of the detergents was very small $(0.01 \%)$, it had a significant effect on the value of the tested parameter. Acid-based formulations (Benamin SND and Randklar S) lowered the $\mathrm{pH}$ level. The most noticeable drop was recorded in a sample of water with Ranklar S detergent $(\mathrm{pH}=3.30)$. Similarly, a pool formulation additive containing a base (Benamin AKR, Randklar A) resulted in an increase in $\mathrm{pH}$. The highest increase in this parameter was seen in the Benamin AKR sample $(\mathrm{pH}=8.76)$.

COD allows us to determine the content of easily oxidizing organic substances that may affect the formation of DBPs. This is one of the parameters that shows the degree of water contamination, while conductivity is a measure of water susceptibility to the flow of electric current. The measurement of conductivity is evidence of mineral water pollution [18]. After the addition of the cleaning agents to the swimming pool water, no significant effect was found on the electrical conductivity nor oxidation. The conductivity and COD values did not exceed the acceptable standards [17]. The studies show that, after dilution of the formulations with pool water, the total nitrogen concentration decreased by $10-15 \%$. Because chloramines are produced by chlorine's reaction with nitrogen-based pollution, it is worthwhile to monitor the organic nitrogen in pool water. The total pool phosphorus value was below the limit of determination $\left(<0.05 \mathrm{mg} \mathrm{P} / \mathrm{dm}^{3}\right)$, while the swimming pool samples containing diluted cleaners increased the content of this biogene. The highest increase was observed with the additions of Benamin SND and Randklar S $\left(8.80\right.$ and $3.30 \mathrm{mg} \mathrm{P} / \mathrm{dm}^{3}$, respectively) and almost-ten-times-lower concentrations were observed for Benam-

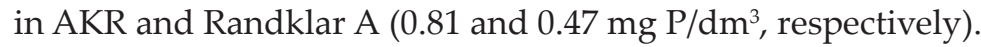


The results of the research on the chloramine formation potential are presented in Table 3 and Figure 1. Chlorine in swimming pool water may be free or bound chlorine; i.e., in the form of chloramines. According to the Regulation of the Minister of Health on the requirements to be met by swimming pool water, pool water should not contain more than $0.3 \mathrm{mg} \mathrm{Cl} / \mathrm{dm}^{3}$ of bound chlorine. Pool water treatment systems work in a cycle of coagulation $\rightarrow$ filtration $\rightarrow$ chlorination. During chlorination, chlorine is bound with water contaminations by forming by-products of water disinfection. After the oxidation of the pollutants, chlorine disinfection (free chlorine) is activated; this destroys the pathogens. Therefore, an important aspect is to measure the free chlorine as well as control the bound chlorine. At present, the regulation lacks standards concerning the limit values of particular types of chloramines.

Table 3. Potential of formation chloramines in pool water depending on detergents

\begin{tabular}{|c|c|c|c|c|c|}
\hline \multirow[t]{2}{*}{ Water samples } & \multirow[t]{2}{*}{ Symbol } & $\mathrm{NH}_{2} \mathrm{Cl}$ & $\mathrm{NHCl}_{2}$ & $\mathrm{NCl}_{3}$ & $\begin{array}{c}\text { Sum of } \\
\text { chloramines }\end{array}$ \\
\hline & & \multicolumn{4}{|c|}{$\left[\mathrm{mg} \mathrm{Cl}_{2} / \mathrm{dm}^{3}\right]$} \\
\hline Pool water & B0 & 0.12 & 0.28 & 0.06 & 0.47 \\
\hline B0+Benamin SND & B1 & 012 & 0.10 & 0.72 & 0.94 \\
\hline B0+Benamin AKR & B2 & 0.22 & 0.61 & 0.00 & 0.83 \\
\hline B0+Ranklar S & B3 & 0.16 & 0.03 & 0.91 & 1.09 \\
\hline B0+Ranklar A & B4 & 0.24 & 0.31 & 0.09 & 0.63 \\
\hline
\end{tabular}

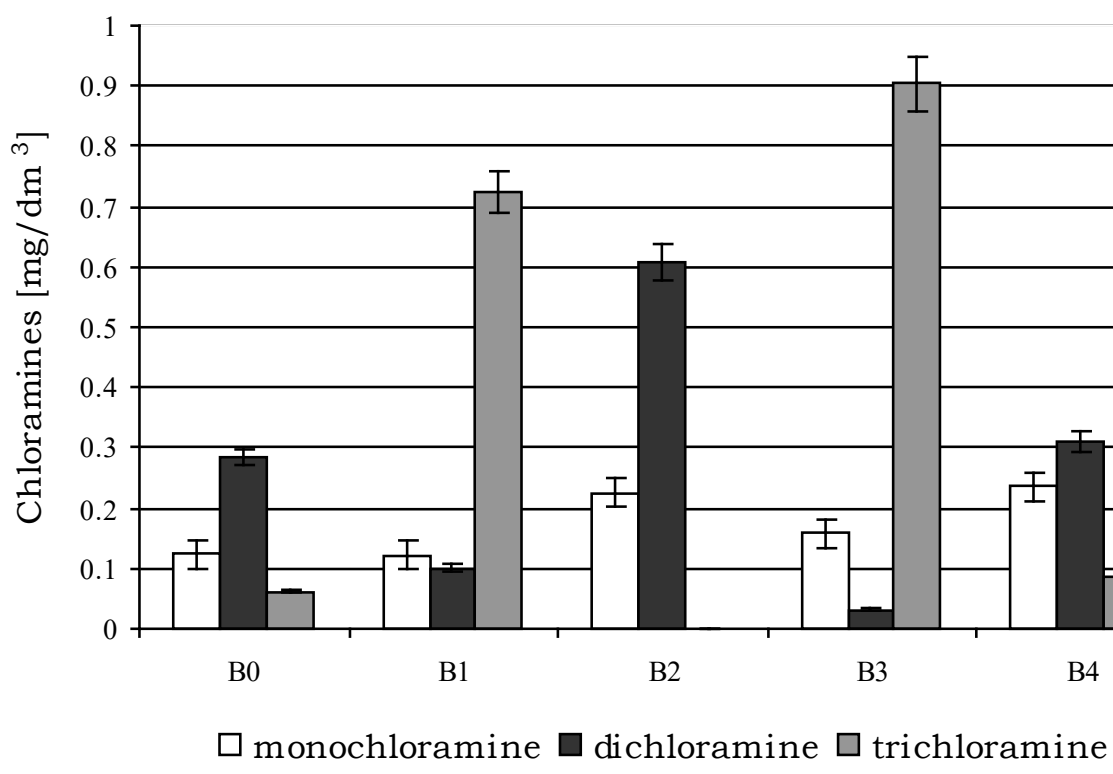

Fig. 1. Distribution of the chloramines in tasted water samples 
Based on research into the chloramine formation's potential, the content of monochloramine in the water samples treated with Randklar S and Benamin SND was not changed or slightly increased. A two-fold increase in this parameter was observed in Randklar A and Benamin AKR. The formation of a particular type of chloramine depends on the water $\mathrm{pH}$ level, alkalinity, temperature, and present ratio of chlorium to ammonic nitrogen (with a ratio of $\mathrm{Cl}_{2} / \mathrm{N}_{-} \mathrm{NH}_{4}$ of $<3 / 1$, monochloramines are produced, and dichloramines are produced with higher $\mathrm{Cl}_{2} / \mathrm{N}_{-} \mathrm{NH}_{4}$ values), among others. Monochloramines $\left(\mathrm{NH}_{2} \mathrm{Cl}\right)$ are formed mainly at $\mathrm{pH}>7$ [14]. Randklar A is based on potassium hydroxide and Benamin AKR on caustic soda. These are high-alkaline products, so adding them to swimming pool water raises the $\mathrm{pH}$ level, thus creating favorable conditions for the formation of monochloramine. This fact is reflected in the obtained results. In the experiment, the concentration of dichloramine in the pool water was $0.28 \mathrm{mg} \mathrm{Cl}_{2} / \mathrm{dm}^{3}$. The addition of Benamin SND and Ranklar $\mathrm{S}$ resulted in a decrease of $\mathrm{NH}_{2} \mathrm{Cl}$ to 0.10 and $0.03 \mathrm{mg} \mathrm{Cl} / \mathrm{dm}^{3}$, respectively, and a three-fold increase after the addition of Benin AKR.

Trichloramines are mainly formed at $\mathrm{pH}<5$ [14]. In the tested pool water, the concentration of this compound was $0.062 \mathrm{mg} \mathrm{Cl} / \mathrm{dm}^{3}$. After the addition of Randklar A, no significant increase of nitrogen trichloride was observed. The same tendency was observed with Benamin AKR; both detergents are strongly alkaline, which confirms that such an environment does not favor the formation of $\mathrm{NCl}_{3}$. The largest increase in trichloramine was observed with Randklar S, a detergent based mainly on hydrochloric acid $(\mathrm{HCl})$. In this case, a 14-fold increase in $\mathrm{NCl}_{3}$ was noted. $\mathrm{HCl}$ (otherwise referred to as hydrochloric acid) is an inorganic chemical of the anaerobic acid group that is an aqueous solution of hydrogen chloride gas. Hydrochloric acid dissolved in water is almost completely dissociated to give $\mathrm{H}_{3} \mathrm{O}$ and $\mathrm{Cl}^{-}$. As the result, the weight ratio of $\mathrm{Cl}_{2} / \mathrm{N}_{-} \mathrm{NH}_{4}$ could have been increased. The addition of Benamin SND to the pool water also increased the monochloramine. This trend is consistent with the literature that acidic $\mathrm{pHs}$ promote the formation of $\mathrm{NCl}_{3}$.

The average chloramine content in pool water was $0.47 \mathrm{mg} \mathrm{Cl}_{2} / \mathrm{dm}^{3}$, indicating that the acceptable levels were exceeded. After adding the detergent additive, the average chlorine content was increased in each case. This study shows that the analyzed cleaning agents used in the swimming pool may cause an increase in the concentration of chloramines in the pool water.

The percentage of individual chloramines in the total chlorine content is shown in Figure 2. When analyzing the results, it can be assumed that the reaction of the used cleansing agent can be attributed to the percentage of the individual chloramines. In pool water without detergent additives, the percentages of $\mathrm{NH}_{2} \mathrm{Cl}$, $\mathrm{NHCl}_{2}$, and $\mathrm{NCl}_{3}$ were 61, 26, and 13\%, respectively. Dichloramine was the dominant compound. In the samples of water containing Benamin AKR purifiers, Randklar A trichloramine was not formed or occurred in minimal quantities due to the alkaline environment. For Randklar $\mathrm{A}$, the percentage share of $\mathrm{NH}_{2} \mathrm{Cl}, \mathrm{NHCl}_{2}$, and $\mathrm{NCl}_{3}$ was 38,48, and 14\%, respectively. In the case of Benamin AKR, the fraction 
was only decomposed between $\mathrm{NH}_{2} \mathrm{Cl}$ and $\mathrm{NHCl}_{2}$ (27 and $73 \%$, respectively). The addition of acid-based preparations changed the percentages of the disinfection byproducts tested, and the share of trichloramine was predominate. Thus, for Benamin SND the percentage share of $\mathrm{NCl}_{3}$ was as high as $76 \%$ and for Randklar $\mathrm{S}-82 \%$. While the concentration of $\mathrm{NHCl}_{2}$ was the lowest for Benamin SND $(11 \%)$ and lower than $1 \%$ for Randklar S.

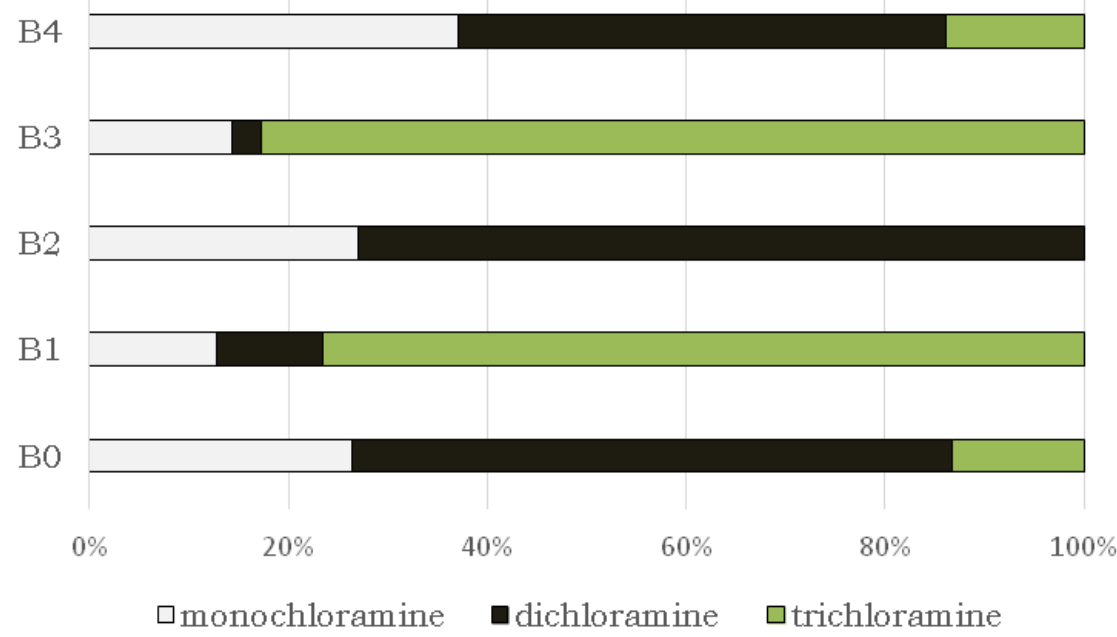

Fig. 2. Percentage of individual chloramines in total chlorine content

\section{Conclusions}

Studies have shown that cleaning agents used in swimming pools can influence the formation of chloramines in swimming pool water. Each time detergents are added, the growth of the chlorine bound in the samples tested is observed. The highest increase was observed with the addition of Randklar S, and the smallest occurred in the case of Randklar A. It was found that the type of detergent used was reflected in the percentage distribution of individual chloramines and also favored the formation of a specific group of disinfection by-products. Those products whose composition was based on acids favored the formation of trichloramine, and those with the high $\mathrm{pH}$ (bases) - dichloramine. From the point of view of the safety of swimming pools and staffs, the chloramine in pool water should be monitored periodically as well as the interactions of particular factors likely to affect the formation of by-products of pool water disinfection. The use of cleaning agents in swimming pools is undoubtedly necessary to maintain the proper hygiene of the pools, but it should be borne in mind that the inappropriate selection of preparations may be 
harmful. The studies and results obtained show the need to create standards and regulations that could greatly facilitate the selection of specific formulations that would not only be effective but also safe.

\section{References}

[1] Wichrowska B., Stankiewicz A., Jankowska D., Życiński D.: Podział i stosowanie środków chemicznych do uzdatniania wody oraz środków do utrzymania czystości w otoczeniu basenów publicznych i prywatnych. Instal, nr 11, 2000, pp. 40-50.

[2] Nawrocki J.: Uboczne produkty dezynfekcji wody - doświadczenia ostatnich 30 lat. Ochrona Środowiska, r. 27, nr 4, 2005, pp. 3-12.

[3] Rook J.J.: Formation of haloforms during chlorination of natural waters. Journal of Water Treatment Examination, vol. 23, no. 2, 1974, pp. 234-243.

[4] Chowdhury S., Alhooshani K., Karanfi T.: Disinfection by-products in swimming pool: Occurrences, implications and future needs. Water Research, vol. 53, 2014, pp. 68-109

[5] Daiber E.J., DeMarini D.M., Ravuri S.A., Liberatore H.K., Cuthbertson A.A., Thompson-Klemish A., Richardson S.D.: Progressive Increase in Disinfection Byproducts and Mutagenicity from Source to Tap to Swimming Pool and Spa Water: Impact of Human Inputs. Environmental Science and Technology, vol. 50, no. 13, 2016, pp. 6652-6662.

[6] Włodyka-Bergier A., Bergier T.: Impact of UV disinfection on the potential of model organic-nitrogen precursors to form chlorination by-products in swimming pool water. Desalination and Water Treatment, vol. 57, no. 3, 2016, pp. 1499-1507.

[7] Zwiener C., Richardson S.D., De Marini D.M., Grummt T., Glauner T., Frimmel F.H.: Drowning in disinfection byproducts? Assessing swimming pool water. Environmental Science and Technology, vol. 41, no. 2, 2007, pp. 363-372.

[8] Richardson S.D., DeMarini D.M., Kogevinas M., Fernandez P., Marco E., Lourencetti C., Ballesté C., Heederik D., Meliefste K., McKague A.B.: What's in the pool? A comprehensive identification of disinfection by-products and assessment of mutagenicity of chlorinated and brominated swimming pool water. Environmental Health Perspectives, vol. 118(11), 2010, pp. 1523-1530

[9] Villanueva C.M., Cantor K.P., Grimalt J.O., Malats N., Silverman D., Tardon A., Marcos R.:. Bladder cancer and exposure to water disinfection by-products through ingestion, bathing, showering, and swimming in pools. American Journal of Epidemiology, vol. 165, no. 2, 2007, pp. 148-156.

[10] Hard G.C., Boorman G.A., Wolf D.C.: Re-evaluation of the 2-yearchloroform drinking water carcinogenicity bioassay in Osborne-Mendel rats supports chronic renal tubule injury as the mode of action underlying the renal tumor response. Toxicological Sciences, vol. 53, 2000, pp. 237-244. 
[11] IARC: IARC Monographs on Chloramine, Chloral and Chloral Hydrate, Dichloroacetic Acid, Trichloroacetic Acid and 3-Chloro-4-(dichloromethyl)-5hydroxy-2(5H)-furanone). International Agency for Research on Cancer, Lyon 2004.

[12] Li J., Blatchley E.R.: Volatile disinfection byproduct formation resulting from chlorination of organic-nitrogen precursors in swimming pools. Environmental Science and Technology, vol. 41, no. 19, 2007, pp. 6732-6739.

[13] Parrat J., Donzé G., Iseli C., Perret D., Tomicic C., Schenk O.: Assessment of occupational and public exposure to trichloramine in Swiss indoor swimming pools: a proposal for an occupational exposure limit. Annals of Occupational Hygiene, vol. 56, no. 3, 2012, pp. 264-277.

[14] Thickett K.M., McCoach J.S., Gerber J.M., Sadhra S., Burge P.S.: Occupational asthma caused by chloramines in indoor swimming-pool air. European Respiratory Journal, vol. 19, no. 5, 2002, pp. 827-832.

[15] WHO: Chemical Hazards. Guidelines for Safe Recreational-water Environments, Vol. 2, Swimming Pools, Spas and Similar Recreational-water Environment, Final Draft for Consultation. World Health Organization, Geneva 2006.

[16] Cimetiere N., De Laat J.: Effects of UV-dechloramination of swimming pool water on the formation of disinfection by-products: A lab-scale study. Microchemical Journal, vol. 112, 2014, pp. 34-41.

[17] Rozporzadzenie Ministra Zdrowia z dnia 9 listopada 2015 r. w sprawie wymagań, jakim powinna odpowiadać woda na ptywalniach. Dz.U. 2015, poz. 2016 [Regulation of the Minister of Health of 9 November 2015 on the requirements to be met by water in swimming pools. Journal of Laws 2015, item 2016].

[18] Kowal A.L., Świderska-Bróż M.: Oczyszczanie wody: podstawy teoretyczne $i$ technologiczne, procesy i urzadzenia. Wydawnictwo Naukowe PWN, Warszawa 2009.

\section{Wpływ środków czystości stosowanych na pływalniach na powstawanie chloramin $w$ wodzie basenowej}

Streszczenie: Środki czystości stosowane na pływalniach są istotnym elementem w procesie utrzymywania należytych warunków sanitarno-higienicznych. Mogą być również przyczyną zanieczyszczenia wody, a także stanowić potencjalne zagrożenie zdrowotne dla użytkowników pływalni. Badania naukowe pokazują że połączenie substancji stosowanych podczas dezynfekcji z niektórymi zanieczyszczeniami wody basenowej może powodować powstawanie wielu groźnych produktów ubocznych. Jednym z nich są chloraminy wykazujące właściwości kancerogenne i mutagenne. Analiza czynników mających wpływ na ich powstawanie jest zatem bardzo ważna. Celem artykułu było określenie wpływu środków czystości stosowanych na pływalniach na powstawanie chloramin w wodzie basenowej. Próbki wody basenowej poddawano działaniu 
wybranych detergentów (Benamin AKR, Benamin SND, Randklar A, Randklar S), używanych na jednej z krakowskich pływalni, następnie badano je pod kątem zawartości monochloraminy, dichloraminy i trichloraminy. Otrzymane wyniki mogą być pomocne przy podejmowaniu działań łagodzących negatywne skutki używania środków czystości na basenach.

\section{Słowa}

kluczowe: produkty uboczne dezynfekcji wody, chloraminy, środki czystości, chemia basenowa, woda basenowa 